\title{
THE BIRTH OF A NEW NARRATIVE: JEWISH-AMERICAN AUTOBIOGRAPHICAL WRITING
}

\author{
ȘTEFANA IOSIF \\ Alexandru-Ioan Cuza University of Iași
}

\begin{abstract}
The Jewish diaspora quickly became one of the most notable immigrant groups in the American context. Faced with an arduous process of assimilation and acculturation, as exiles, Jews in America felt the pressure of the difficult choice between preserving their tradition and adapting to the new pragmatism and materialism that their new circumstances required. The issue of accelerated assimilation and loss of Jewishness became a real concern. As such, initiatives such as the one proposed by the YIVO Institute of a contest for autobiographical writing belonging to Jewish immigrants, dedicated to protecting Jewishness, offered a forum for personal written histories, submitted in different languages, but united through their English translations. Autobiography, as an essentially American genre, constituted an auspicious venue of expression, thus aiding the communal efforts of (re-)shaping and (re-)defining what it meant to be a Jew and what it meant to be a Jewish-American.
\end{abstract}

Keywords: Autobiographical writing, Jewishness, YIVO contest, memory, Jewish immigration

Currently the largest Jewish diaspora in the world, American Jewry underwent a profoundly laborious process of shaping its identity. Having consolidated its position as an indisputably notable immigrant group, with millions reaching the shores of the New World in multiple waves, particularly from the middle of the 19th century onward, the new Jewish communities were caught in a process of simultaneous mutual change with their new contexts. As such, conscious efforts were crystallized with the purpose of defining and delineating the new ethnic figure of the Jewish-American, all the while attempting to capture the elusive essence of what it meant to be Jewish. One of the countless projects dedicated to this endeavor, the YIVO contest of 1942, "Why I left Europe and what I have accomplished in America," managed the ideal feat of bridging the two worlds of 
the first-generation immigrants, through the means of autobiographical writing, allowing for personal histories to be woven and included in the collective one.

\section{A Historical Overview of the American Jewish Diaspora}

Jewish presence in America dates back to the 17th century, to 1654, when twenty-three Sephardic Jewish refugees from Brazil arrived in New Amsterdam. The initial tradition of American Judaism was Sephardic, given the origins of the initial settlers, who could "trace their ancestry to the Jewish inhabitants of Spain and Portugal” (Faber 24), however the majority of the Jewish population starting with the 18th century is Ashkenazim, in other words, Jews originating from Central and Eastern Europe. Even as early as the 18th century, the dedication of Jews to America, and what would become the United States, makes itself felt, so much so that during the American Revolution "the five small Jewish communities in the newly established United States of America found themselves thoroughly disrupted, with many of their members choosing exile, behind American lines rather than remain in areas under British control" (Faber 30). In other words, when faced with having to choose between supporting the Old World, Europe, or the New World, America, they chose the latter, as it had become their homeland, rather than returning.

After the turn of the 1880s, the climate in Eastern Europe took a definitive turn for the worse. Particularly in Russia, anti-Semitism peaked with a series of mass pogroms in 1881, 1882, 1883, culminating with the May Laws given by tsar Alexander III, which were supposed to be only temporary provisions, but which essentially disenfranchised the Jewish population of Russia, forcing them out of their cities, their businesses, jobs, and homes, and expelling them to the Russian Pale. Amidst the profound lack of opportunity and stability, in addition to their continuous ghettoization, the Jews attempted, at first, to navigate the discriminatory policies and find niches where their skills might provide them with their daily bread and butter. In other words, particularly in light of being denied citizenship, and therefore the right to property, the Jews of Eastern and Central Europe reconfigurated their existence, focusing on specializing on demanding crafts, which they took to the urban areas. Particularly the eyes and hopes of the younger generations were turned towards the bigger cities, away from the traditional shtetls, small towns lacking in true financial prowess and opportunities. Eventually, the dream of accomplishment led them towards America, the fabled Promised Land, away from the strictures and limitations of the Old World.

During the very first decade of the 20th century, over 600,000 Jews entered the United States. "Like most immigrants, the Russian Jews came for a simple reason - to leave hunger and the oppressive regime and to realize the American Promise of abundance and personal freedom” (Gartner 45). America, 
naturally, was presented as a legendary realm in the accounts of those who had already reached it, which only increased the mythological strength of the American Dream. Despite the inherent strictures of immigration, 98\% of newcomers were admitted after the infamous Ellis Island check-point. What is more, although most of them never achieved the fabled abundance, less than a tenth ever returned to Europe, abandoning their hopes for America (Gartner 45). In actuality, despite hardships, America still meant more freedom either to practice Judaism without oppression, or to become part of the secular world, away from Orthodoxy, and thus the freedom to shape one's individual identity.

As time passed, Jews slowly made their way up the American ladder. The "neighborhood of first settlement" was generally exchanged for the "neighborhood of second settlement", to which Jews began to transition. Communities themselves began to change, discarding Old-World differences, merging together and forming bigger synagogues, which could afford professional rabbis, who would provide not only sermons, but teaching and halakhic guidance, as well as hazans (Gartner 50). The emerging new generations had the proper context for a change in their way of life.

However, before long, the Great Depression hit the newly formed middle-class of Jews, as it hit the entire country. Among countless other effects, it automatically led to the disappearance of most of the new synagogues, which intrinsically altered the weave of the Jewish communities. What is more, the climate of the 1930s contoured a fully developed Jewish crisis. During the 1930s, the number of Jewish immigrants from Europe dwindled, mainly because of the new immigration acts of the previous decade, which essentially limited their access, namely the 1921 Immigration Restriction Act and the 1924 National Quota Act, which stemmed from the belief that the forging of a true American identity could only be accomplished by allowing in solely the right type of immigrants, immigrants who could meet the high demands of strict adherence to the values of the cultural majority with respect to "language, religion and manners", while "many felt that America's racial as well as her cultural identity was threatened by unrestricted immigration... [which in turn] threatened economic stability" (Campbell 46). The truth of the matter was that the ideal middle class, Germanic, if not downright Anglo-Saxon, immigrant proved to be far less likely to adapt and assimilate, which is what the social climate would demand. The overwhelming majority of Jews in America, however, seemed to be entirely dedicated to the goal of assimilating to the general population. All cultural and religious specificities were altered so that they would be more in tune with the Anglo model: the religious services gradually resembled Protestant sermons, Yiddish faced near extinction, the newer generations having English strongly imposed on them, since linguistic assimilation would have undoubtedly allowed them to access opportunities otherwise unattainable to "the other." 


\section{Jewish Autobiography - Tradition and Innovation}

Autobiography has traditionally been considered by critics a difficult genre to pin down. The sheer attempt at defining it has proved contentious, as George Misch argues that "its boundaries are more fluid and less definable in relation to form than those of lyric or epic poetry or of drama" (qtd in Gray 32). More often than not, the very notion of the literary quality of autobiography was considered doubtful, since mere self-expression was seen as insufficient for critical consideration. What is inescapable is the intrinsic human need to explore and detail their journey of self-discovery. Particularly given the modern centrality of the question of identity, it has virtually overturned previous preconceptions on autobiography, as a literary genre. However, one must not fall into the trap of limiting the scope of autobiographical writing to modern or even contemporary times. Particularly in the American context, a Protestant tradition of selfsearching can be distinguished "in the seventeenth century and afterward... which taught men that the scrutiny of their souls was an infinitely important business" (Gray 31). The rise of the individual over the mere collective across the Atlantic was a revolutionary act in itself. The focus is shifted from the larger contexts of group history, or even the higher contexts of social hierarchy. In its revolution, autobiography now allows the individual to formulate their own relevance not only in terms of their own existence, but as an influence and a direct participant in the inner-workings and making of history. Otherwise put, "it signifies an assertion of ego in an insecure world, a search for personal power when one fears the eclipse of the individual person, a way to define identity" (Gray 32).

Marcus Moseley argues that, in fact, "the emergence of autobiography is coextensive with the emergence of historical consciousness, discovery of self, validation of the individual” (1). But even that rise of the self, being profoundly politicized, makes way for a rejection of canonical autobiography, which "is often viewed with barely disguised hostility, even paranoia, as the 'locus of monumental Western selfhood',... 'a First World genre of the dominant culture'... 'policed' to exclude non-normative works and so forth” (Moseley 1). Even with its marginalized status, autobiographical writing still thrives, particularly in the context of the New World, refusing the strictures of clear definitions. As such, through the "protean nature of the genre itself, porous, elastic, and polymorphous... autobiography embraces myriad purposes and comes in countless guises” (Gray 32), which consequently allows previously marginalized groups a venue for self-expression, one that could be moulded to their own unique cultural needs. Particularly among feminists and minorities, autobiographical writing, novelistic or otherwise, takes strong roots, aiding their emerging efforts for value and visibility. 
The Jewish cultural group is no exception. In fact, as Moseley corroborates, Jewish autobiographies date back to the Middle Ages, however "such works, though, do not arise from within the tradition but are invariably prompted by external circumstance, namely, a catastrophic occurrence of personal or national dimensions” (72). Additionally, as Haskalah, or the Jewish Enlightenment make a stronger case for the emancipation of the individual through knowledge, within the Jewish maskilic tradition, one would explore their journey to knowledge, as reference for future generations. What does seem to differentiate earlier Jewish autobiographical writing from other Western ones is their being included in a collective, communal sentiment. In other words, the autobiography of the Jewish individual would play within a larger scheme of collective needs and learning. According to Moseley, "the focus of Jewish autobiography, in distinction to non-Jewish, is not upon the self of the author but upon the community, the first-person singular of the autobiographical narrator being, in effect, a trope for the first-person plural of the collective... [subjectivizing] the collective” (Moseley 73).

\section{Yivo Autobiography Contest of 1942}

Between 1939 and 1945, the entire world was caught in the throes of the chaos of the Second World War. The Jewish people were facing an unprecedented attack not only on their lives, but on their sheer existence in history. In their maniacal plans, as Elie Wiesel himself states in the Preface of the new edition of his visceral autobiography, Night, "the war which Hitler and his accomplices waged was a war not only against Jewish men, women, and children, but also against Jewish religion, Jewish culture, Jewish tradition, therefore Jewish memory" (Preface n.pag). The entire experience was a whirlwind of dehumanizing senselessness and aggression. Wiesel concludes that his rescued life was to be dedicated to his quest of being a "witness who believes he has a moral obligation to try to prevent the enemy from enjoying one last victory by allowing his crimes to be erased from human memory" (Preface n.pag), therefore insisting on the vital importance of memory in the continued fight against the genocide and the Nazi attempt to entirely wipe Jewry, Judaism and Jewishness not only from the face of the planet, but from its history and memory, even (and perhaps most importantly) after the official end of the war. At no moment in time had it been more poignantly necessary to commit to universal memory the surviving elements of a deracinated and decimated world.

At the beginning of the 1940s, the YIVO Institute was an immigrant institution, uprooted from Vilna and transplanted to safety on the transatlantic shores. Under the guidance of its research director, Max Weinreich, the YIVO Institute had dedicated its efforts, while in Europe, to elevating Yiddish out of the cone of shadow that had engulfed it, and preserving Yiddishkeit as an organic 
element of Jewishness. It was meant as a cure for the dwindling of Judaic religious tenets, overthrown by an ever more secular world, which could have, and possibly would have meant an increased loss of Jewish cultural heritage. With the Nazi threat approaching, the Institute found a new home in America, where it continued its devoted work to Jewishness, but now, they, like all immigrants, were required to bridge the gap between the Old World and the New World, and find means through which their work would be considered relevant in their new context, and which would meet the needs of the Jewish communities in America, immigrants and their descendents. In fact, in addition to the horrors of the war in Europe, the YIVO Institute became very much aware of another phenomenon that was threatening Jewish identity. The previous six decades had borne witness to an entirely revolutionary migratory movement. Millions of Jews had relocated to the United States, in their search for a better life. These first generations of immigrants were ageing, however. Their stories and their unique experience were facing a real risk of being forgotten. This would essentially cut the ties between future generations and the history of their forerunners. It was here that Weinreich and the Institute realized their "specifically American mission" (Soyer 221).

In 1942, the YIVO Institute formulates a contest aimed at the first generation Jewish immigrants, with the theme Why I left Europe and what I have accomplished in America, which allowed for previously unheard voices to manifest themselves and bear testimony to "the social dislocation that first caused... the migration process itself... [and to] stories of reintegration and resocialization in the United States" (Soyer 225). In an action that proved to have a vision decades ahead of its time, the contest brought in an enormous amount of participants, "in all, 223 individuals composed autobiographies, contributing approximately 25,000 pages of material” (Soyer 227). The tapestry created was indeed unprecedented in its nature. The value of these autobiographical writings related not to literariness, but to cultural impact. It brought the individual account centerstage, allowing for personal life histories to truly contribute to the general cultural context of American Jewry. As Weinreich repeatedly told participants, "there is no human life... that is not interesting to science" (qtd in Cohen, Soyer 6). In one fell swoop, the lives of "simple" people became the principal device that would aid the welding together of a true communal spirit among Jews in America, not allowing for their heritage to be lost, as "Weinreich thought a healthy ethnic communal life necessary for the emotional health of its individual members" (Soyer 222). And indeed, this did prove to be a profoundly emotional endeavor, with writers recollecting their long-lost childhood, families left behind, a vanishing mode of life, now etched only in their imagination and memory, but also their self-actualization in their new lives, their survival, and their stories of success and thriving. 
In a true feat of blurring genre delineations, the YIVO autobiographies combine writing traditions in a symbolic, albeit unconscious gesture of uniting the multiple sides of their lives. Three main traditions of autobiographical writing can be extracted and found overlapping in the texts submitted by the two hundred participants to the contest. The first strand is the maskilic autobiography, the "modern Jewish autobiography... directly inspired by [Rousseau's] Confessions" (Litvak 8), emerged in the middle of the Jewish Enlightenment, Haskalah. This movement's main dictum was the elevation of the individual through knowledge, "the idea of Jewish regeneration [through] ... independent thought” (Litvak 22). Haskalah implied a sense of evolution of the individual through knowledge. Maskilic autobiographies, then, named after the practicers and supporters of the movement, called the maskilim, revolved around the writer's emancipation through "wordly", secular learning. Secondly, as a most appropriate companion, we can distinguish the Socialist autobiography, "profoundly influenced by the Socialist movement... the story of the young worker... oblivious to the ruthless, impersonal forces of capitalist exploitation" until their moment of Socialist enlightenment (Cohen, Soyer 11) allows them to reshape and reconfigure their lives and their principles. As such, the measure of their accomplishment is taken very differently. Material gains somehow lose their lustre to a new civil religion, which would dictate a fight for equality of rights and opportunities for the disenfranchised. In fact, civil religion itself seemed to slowly replace religiosity, particularly in the Socialist context, "the fundamental 'dogma' of the civil religion of American Jewry became 'Jewish survival'”, which intrinsically also became the cornerstone of their spirituality and commonality, as "the people of Israel replaced the God of Israel" (Sherwin 118). Perhaps surprisingly, the American-themed autobiography accompanies the first two. Bearing in mind, however, the dire contexts that these immigrants had originally left behind, the reality of discrimination, lack of rights, and profound pauperity in many cases, the American rhetoric of the poor immigrant succeeding in the "Promised Land" takes on an entirely understandable valency. As Hana Wirth-Nesher very adeptly notices, "becoming an American is the sine qua non and perhaps the recurring and dominant theme of American autobiography", in other words "the extent to which the autobiographer is selfconsciously a representative American" takes center stage (Nesher 113). As such, "authors often combined the story of their upward mobility with that of their continued commitment to the Socialist cause" (Cohen, Soyer 12). They are essentially the stories of surviving their deracination and adapting to the new context, climbing the social and economic ladder as part of the American Dream.

Minnie Goldstein, born in 1882 in Poland, submitted her own account which seamlessly encompasses all three types of autobiography. Minnie came as a young girl of twelve to America. When she reached the transatlantic world, 
she was illiterate and destitute, but determined. She had dreamed of "a country where everyone is equal... and work is no disgrace" (Goldstein 21), so her story of American emancipation is tightly connected to that of hard work. Her entrepreneurship helps elevate her family slowly, first by buying and managing a candy store, to make up for the lack of employment, then by purchasing real estate, and selling it for a profit. In a twist of narrative, it is she that holds economic prowess, while her husband struggles with failed business ventures and debt, out of which she rescues him. Furthermore, as with numerous other instances of immigrant writing, her American Dream comes to fruition through the success of her children, to whom she offers the opportunities she did not herself have access to, stating "I felt very fortunate to know that with my help I was able to succeed in giving our children such a good education... it would not have been possible without my assistance” (Goldstein 31). But along with offering her children the opportunity of education, she makes up for the lack thereof she herself suffered in her childhood, and amid her caring for her ailing child, and managing her affairs, she dedicates her energy and efforts to learning how to read and write. This is facilitated by the government programs, dedicated to older people, which she sees as a gift from God (Goldstein 32), and which seem to offer one more confirmation of America as the Promised Land, where everyone could fulfill their aspirations, through mere determined application.

The YIVO contest accomplished an astounding feat of collaborative work. Unlike more famous, and more literarily valuable autobiographies, such as Mary Antin's, which were written only in English and with a gentile reader in mind, the two hundred works served an entirely different purpose. Rather than advocating for assimilation and profound Americanization, they offer a treasury of cultural testimonies, written mostly in Yiddish, as well as Hebrew, or German, by Jews, and, even more importantly, for Jews. And although only a small fraction of the 25,000 pages of works have received critical attention, the collection provided authentic accounts of survival and skillful navigation of ever-growing pressures of conforming, and yet resisting shedding their ethnic and religious specificities, accounts which created a sense of community and of shared memory and knowledge, leaving future generations the inheritance of a complex web of lives lived in what would have otherwise been a forgotten world.

\section{References}

Adler, Eliyana R. "Bildungs Romance: East European Jews and the Desire for Education.” The Jewish Quarterly Review, vol. 106, no. 3, 2016, pp. 419-426. Web. JSTOR, www.jstor.org/stable/jewiquarrevi.106.3.419. Accessed 4 Jan. 2020.

Campbell, Neil and Alasdair Kean. American Cultural Studies: An Introduction to American Culture. London: Routledge, 2002. Print. 
Cohen, Jocelyn, Daniel Soyer, eds. My Future Is in America: Autobiographies of Eastern European Jewish Immigrants. New York: New York University Press. 2006. Print.

Faber, Eli. "Preservation to innovation: Judaism in America, 1654-1880." The Cambridge Companion to American Judaism, edited by Dana Evan Kaplan, Cambridge University Press, 2005, pp. 23-42. Print.

Gartner, Lloyd P. History of the Jews in Modern Times. Oxford: Oxford University Press, 2001. Print.

---. “American Judaism.” The Cambridge Companion to American Judaism, edited by Dana Evan Kaplan. Cambridge: Cambridge University Press. 2005. Pp.43-60. Print.

Goldstein, Minnie. “Success or Failure?” Cohen, Jocelyn, Daniel Soyer, eds. My Future Is in America: Autobiographies of Eastern European Jewish Immigrants. New York: New York University Press. 2006. Print.

Gray, Rockwell. “Autobiography Now.” The Kenyon Review, vol. 4, no. 1, 1982, pp. 31-55. JSTOR, www.jstor.org/stable/4335252. Web. Accessed 4 Jan. 2020.

Litvak, Olga. Haskalah: the Romantic Movement in Judaism. New Brunswick: Rutgers University Press. 2012. Print.

Moseley, Marcus. Being for Myself Alone: Origins of Jewish Autobiography. Stanford: Stanford University Press. 2006. Print.

Sherwin, Byron L. “Thinking Judaism through: Jewish theology in America.” The Cambridge Companion to American Judaism, edited by Dana Evan Kaplan. Cambridge: Cambridge University Press. 2005. Pp.133-145. Print.

Soyer, Daniel. "Documenting Immigrant Lives at an Immigrant Institution: Yivo's Autobiography Contest of 1942.” Jewish Social Studies, vol. 5, no. 3, 1999, pp. 218-243. JSTOR, www.jstor.org/stable/4467560. Web. Accessed 4 Jan. 2020.

Soyer, Daniel. "The Voices of Jewish Immigrant Mothers in the Yivo American Jewish Autobiography Collection.” Journal of American Ethnic History, vol. 17, no. 4, 1998, pp. 87-94. JSTOR, www.jstor.org/stable/27502338. Web. Accessed 5 Jan. 2020.

Wiesel, Elie. Night. New York: Hill and Wang. 2006. Print.

Wirth-nesher, Hana. "Introduction: Jewish-American Autobiography.” Prooftexts, vol. 18, no. 2, 1998, pp. 113-120. JSTOR, www.jstor.org/stable/20689510. Web. Accessed 5 Jan. 2020.

\section{BIONOTE}

Ștefana Iosif is a $\mathrm{PhD}$ student at Alexandru Ioan Cuza University of Iași, conducting research focused on Jewish-American autobiographical writings. Additionally, she is an associate teaching assistant at the university level, with classes varying from Conversation Practicum to Medical English. She is an avid feminist and humanist, taking a special interest in social and cultural issues. E-mail: stefana_isf@yahoo.com 
